\title{
Figure S5
}

\section{Plate 1}

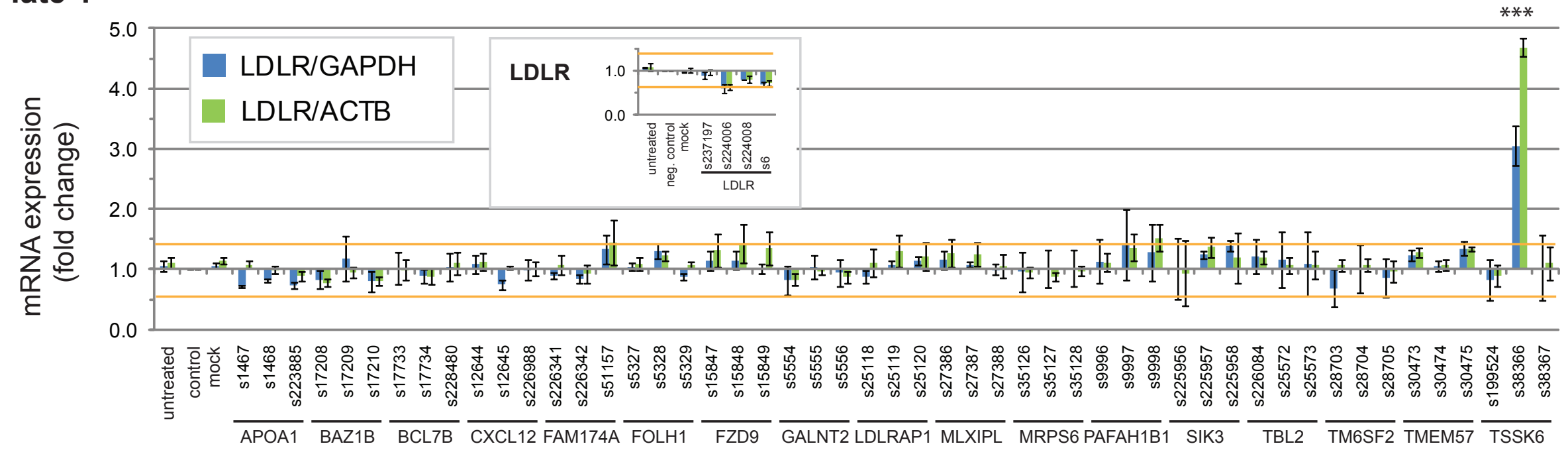

\section{Plate 2}

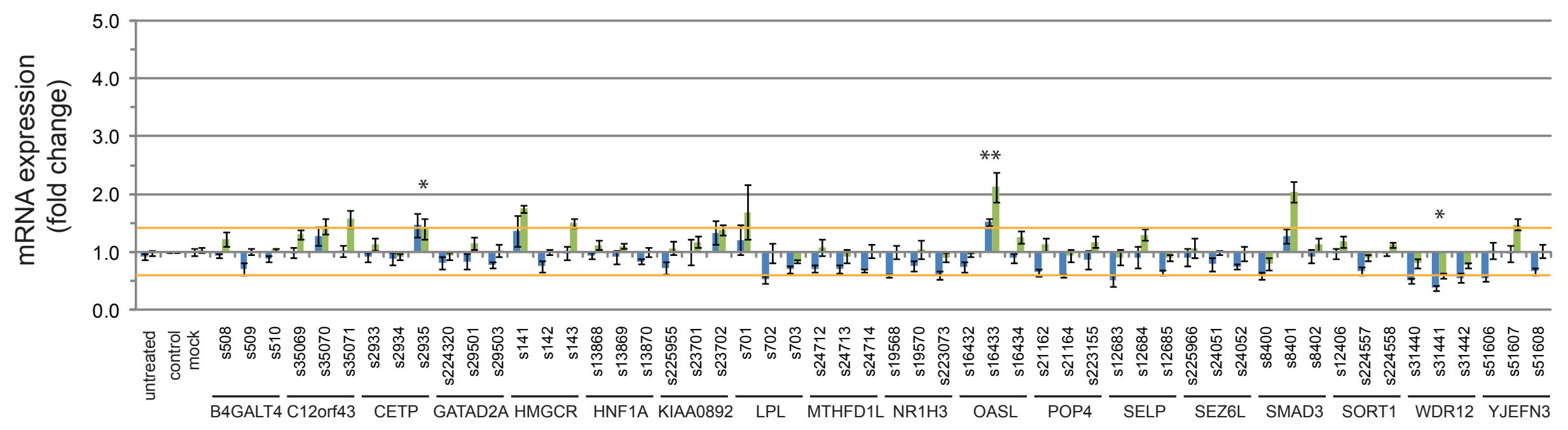

